\title{
MORE KUYPERANIA
}

\section{Author:}

S. Bishop ${ }^{1}$

\section{Affiliation:}

${ }^{1}$ City of Bristol College, Bristol, 100 North Rd, Stoke Gifford, Bristol BS34 8PE, England

\section{Correspondence to:}

S. Bishop

\section{Email:}

stevebishop.uk@gmail.com

\section{Postal address:}

100 North Rd, Stoke Gifford, Bristol BS34 8PE, England

\section{Dates:}

8 Dec 2015

How to cite this article: Bishop, S., 2015. "More Kuyperania". KOERS - Bulletin for Christian Scholarship, 80(3). Available at: http:// dx.doi.org/10.19108/ koers.80.3.2240

\section{Copyright:}

(C) 2015. The Author(s).

Published under the

Creative Commons

Atribution License.
This article is a review of four recent books on Kuyper. What these books show is that Kuyper's Calvinism was not restricted to soteriology; his approach was, based on the sovereignty of God, cosmocentric rather than anthropocentric. His Christianity was integral to all that he did from theology to politics and education.

Hierdie artikel is 'n oorsig oor die vier mees onlangse boeke oor Kuyper. Wat hierdie boeke uitwys is dat Kuyper se Calvinisme nie beperk is tot soteriologie nie; sy benadering, gebaseer op die soewereiniteit van God, is kosmosentries eerder as antroposentries. Sy Christenskap was 'n integrale deel van alles wat hy gedoen het, van die teologie tot politiek en opvoedkunde.

\section{INTRODUCTION}

Since the publication of 'Recent kuyperania' (Bishop 2014) four more important Abraham Kuyper (1837-1920) books have been published. All four are translations into English from Dutch works, three by Kuyper (2013a, 2013b, 2014) and the fourth about Kuyper (de Bruijn 2014). The publication of these works once more shows how important Kuyper is for today.

The three translations of works by Kuyper are part of the on-going Kuyper Translation Project. These books show the facets of Kuyper's career as a theologian, an educator and a politician persuasively.

\section{COMMON GRACE}

Common grace has always been a controversial subject viewed with either suspicion or distaste by those who do not embrace it. In 1895 Abraham Kuyper began a series of newspaper articles on common grace. They were completed in 1901 and were then published in book form as De gemeene gratie in 1902.13, 1903.13 and 1905.08 (dates are those given in Kuipers 2011). There are hints of common grace in Calvin and Kuyper sees himself writing in Calvin's line. Before Kuyper's book Herman Bavinck in his 1894 Kampen rectorial address had traced the roots of the idea to Calvin (Bavinck 1989), but here we have the first full treatment of common grace.

Kuyper began these writings at the peak of his career; the books were published during his time as prime minister. Common grace 1.1 (Kuyper 2013a) is the first volume of the English translation and covers a third of the original Dutch volume (from Noah to Abraham). The complete English translation is proposed to be in ten volumes - the tenth will be a comprehensive index. ${ }^{1}$

Richard Mouw, in the introduction, describes Kuyper as an activist (p. xxix) as well as a churchman (p. xxiv) and a 'multi-tasker' (p. xxiv) who did 'theology on the run' (p. xxiv). Mouw stresses that Kuyper with his emphasis on common grace does not reject the notion of the antithesis. Kuyper was a good Calvinist and held to the doctrine of 'total depravity'. Kuyper saw his common grace project as a development of Calvin², and Mouw emphasises this continuity between Calvin and Kuyper. Mouw sees Kuyper's common grace as ‘a divine strategy for bringing the cultural designs of God to completion' (p. xxv).

Kuyper begins his foreword with this provocative statement: 'The Reformed paradigm

$1 \quad$ The volume is translated by Nelson Kloosterman and Ed M. van der Maas on behalf of the Abraham Kuyper Translation Project and the Acton Institute. The foreword was written by the editors, Jordan Ballor and Stephen Graybill.

2 Calvin never used the term 'common' to preface grace, he seemed to prefer the term 'peculiar' 
has suffered no damage greater than its deficient development of the doctrine of common grace' (p. 3). $\mathrm{He}$ then goes on to lament the lack of doctrinal development that occurred in Calvinism after 1650. What happened was only a 'repristinating their well-worn polemic against Arminianism' (p. 5).

For Kuyper common grace is 'deduced directly from the sovereignty of God' and is the 'root and conviction for all Reformed people' (p. 5). Kuyper thinks that resuscitating the doctrine of common grace will help the believer 'take hold of the plow' rather than retreat from the world. Common grace provides the foundation for engagement with the world thus avoiding spiritual and ecclesiastical isolation and thereby helping believers exercise dominion (p. 5).

The length of the chapters betrays its origins as newspaper articles; there are 29 chapters in 249 pages.

The editors note that "There is often a temptation, particularly among evangelicals, to engage in social reform without first developing a coherent social philosophy to guide the agenda' (p. xi). They hope that Kuyper's idea of common grace will help to provide that social philosophy. They see common grace as the 'capstone of Kuyper's constructive public theology' (p. xi).

A number of interesting/ surprising things developed in the book are:

- $\quad$ The starting point with Noah

- The defence of capital punishment

- That meat-eating took place before the flood. ${ }^{3}$

- The suggestion that the flood was not global in the sense we perceive global to be today.

Why start with the Noahic covenant? Kuyper places much emphasis on the inclusive nature of the Noahic covenant and that it was not a redemptive covenant. The flood changed the state of the earth and the purpose of the covenant was to take into account these changes. This was because of God's grace - a common grace as it applies to all.

This Noahic covenant had largely been neglected, in part because of a dispute between Johannes Cocceius and Gisbertus Voetius over the uniformity of salvation between the Old and New Testaments.

The result was that the entirely unique and principial significance of the Noahic covenant was gradually lost from view. The fact that it concerned 'common grace' and not 'particular grace' was not perceived. (p. 111)

Kuyper places the establishment of government here with the Noahic covenant. This institution of government was to be a means of common grace.
After dealing with the Noahic covenant Kuyper then turns to Adam in Paradise. The main focus is on the issue of original righteousness. This issue, it seems, is central to Kuyper's argument.

He regards the initial Genesis passages as being historical and that Adam's creation was almost instantaneous. This is clear in his discussion of language. He then summarises the main points:

1. The human race, not just a few people, was rescued from the flood. From the eight rescued comes the whole human race.

2. The earth is still the same though it has been changed by the catastrophe of the flood.

3. The atmosphere of the earth was changed.

4. The blessings are not just for the church but for all of humanity and animals.

5. The relationship between humans and animals and the earth is now regulated.

6. A change took place in the life of humanity itself; humanity didn't live for as long.

7. God instituted government for an orderly human life. This was designed to thwart the outbreak of violence.

What is clear from this is that Kuyper has a cosmological rather than an anthropocentric view of the covenant.

This God-given institution of government was a major concern of Kuyper. As well as a theologian Kuyper was a politician and political party organiser - this aspect is seen in his Ons program.

\section{GUIDANCE FOR CHRISTIAN ENGAGEMENT IN GOVERNMENT}

The Antirevolutionary Party (ARP), the first national political party in the Netherlands, was founded on 3 April 1879. Kuyper was its chief architect and leader. He took the movement started by Guillaume Groen Van Prinsterer (1801-1876) and formed it into a political party. Kuyper wrote a series of commentaries on the ARP's political programme, and these were published as an Ons program [Our Programme] in March 1879 (1879.04 in Kuipers, 2011). Guidance for Christian engagement in government (Kuyper 2013b) is the first English translation of Ons program. It provides fascinating reading and insight into what a Christian political programme looked like. Harry Van Dyke does an excellent job as a translator.

As Kuyper points out the ARP had another name: 'Christianhistorical'. The name ARP indicated what they opposed, and the Christian-historical approach was what they promoted. The revolution mentioned in ARP is the French Revolution. The ARP was against the principles that were behind the French Revolution, namely the attempt to place humanity and reason over and above God. The name indicates that the party was a 
'militant party, unhappy with the status quo and ready to critique it, fight it, and change it' (loc $\left.{ }^{4} 229\right)$. Kuyper preferred the term ARP to Christian-historical, as ARP was more 'energetic and compelling' (loc 296).

Kuyper steers a political course between a Calvinistic utopia, which he recognises is untenable, and a political arrangement for 'a pure, unmixed Calvinistic nation' (loc7791). Kuyper didn't intend for a theocracy, unlike the theonomists in the United States who (mis)appropriated some of Kuyper's ideas. Kuyper recognises that what is presented here is a 'rough and very cursory and unfinished sketch of our view of the state' (loc 7791). Nevertheless, this programme was still used by the ARP (with modification in 1916, 1934 and 1961) into the early sixties.

The scope of the topics is impressive: from church and state to overseas development. We have 22 chapters that are a commentary on 21 articles - article 4 is in two sections 4A and B. ${ }^{5}$

The first part focuses on God, as one might expect from a Christian political party manifesto. God is the source of authority for the movement and that authority comes through his ordinances - all else is delegated through the notion of sphere sovereignty. The 'source of authority does not reside in the law or the will of the people but in God' (loc 548); sovereignty 'flows over all creation, not just in the political field but in every domain' (loc 561). It starts with God and flows from him to all of creation. God is no gloss over a secular political philosophy - he is integral in all the positions taken by Kuyper in this programme.

For Kuyper then the role of government is to determine the law of the land and to uphold that law. The laws that the government makes can only be done on the basis that justice already exists. Justice is an ordinance of God and not the whim of the people or of rulers. As Kuyper makes clear:

... sound and comprehensive knowledge of those principles can only be attained by studying God's Word and researching God's ordinances. (loc 743)

The state exists so that communal life can exist; the state is not

\begin{tabular}{ll}
\hline 4 & The term 'loc' indicates the location in the Amazon Kindle edition. \\
5 & The 21 articles cover the following: \\
1. & The movement \\
2. & Authority \\
3. & The ordinances of God \\
4 and 5. & The government and the State \\
6. & The forms of government \\
7. & The constitution \\
8. & Popular influence \\
9. & Budget refusal \\
10. & Decentralisation \\
11. & States and councils \\
12. & Education \\
13. & The justice system \\
14. & Public decency \\
15. & Public hygiene \\
16. & Finance \\
17. & National defence \\
18. & Overseas possessions \\
19. & The social question \\
20. & Church and state \\
21. & Party policy
\end{tabular}

an end in itself. This communal life is only a foretaste of that which will be revealed in the kingdom of God. As the title of chapter 5 states there is no secular state. The state cannot exist without God and so a secular state is a contradiction. There is no private/ public divide in Kuyper's thought. Government is a servant of God and as such Kuyper maintains it should:

allow unrestricted freedom for (a) the gospel's influence; (b) the people's spiritual formation; (c) the manner in which people choose to worship; and (d) people's conscience'. ... government is duty-bound to (a) maintain law and order; (b) honor the oath; and (c) dedicate one day a week to God. (loc 1314)

It is important to remember that Kuyper was writing this when the Netherlands was:

not a nation of atheists but a "Christian nation," we want to give the state a structure that matches that situation in practice-a structure in which the Christian feels at home and which continually reminds the atheist of the undeniable fact that not the Christian but he is the exception and that he is accommodated, to be sure, but only by way of exception (loc. 1413).

The situation is very different today. Today, in most western countries, Christianity is the exception. But what is clear here is that Kuyper does not want a theocracy or a government that eliminates all other opposing views; instead, space is created for opposing religions and worldviews.

Inevitably, this is a document of its time. Some of the Sunday restrictions and alcohol control seem very dated. Vaccinations he thinks should be limited - compulsory cowpox vaccination should be 'out of the question' (loc 5246) - as it means that government is overstepping its bounds: 'the government should keep its hands off or bodies' (loc 5246).

Surprising to those who are not aware of Kuyper's views is the discussion of church and state. He likes the separation of church and state and sees it in a three-fold way: political unity is not coupled to church unity; each have 'a unique zone in life where each functions as a minister of God' (loc 7342); and there should be a bilateral relationship. But what is clear in the programme is that the form of government is 'relatively immaterial' although Kuyper prefers a constitutional monarchy, however, God is the real ruler.

This is not a document that could be adopted wholesale as the manifesto of a contemporary political party; the programme is too historically and geographically bound for that, nevertheless what it does do is show how political principles arise from faith in God. Politics and faith were intertwined for Kuyper. As with politics so too with education and scholarship: scholarship as politics is to be performed under the sovereignty of God. Both require the realisation that they are creaturely and cultural callings but are contaminated by sin and both require the direct revelation of God through his divine ordinances. 


\section{SCHOLARSHIP: TWO CONVOCATION ADDRESSES ON UNIVERSITY LIFE}

This is another addition to the increasing number of Kuyper translations from the Abraham Kuyper Translation Project. The translator is again Harry Van Dyke, who as with the previous work has done an excellent job in making the work readable and in contemporary English. Scholarship (Kuyper 2014) is a translation of two of Kuyper's Rectorial Convocation addresses to students and staff at the Vrije Universiteit (VU)(Free University) in 1889 and in $1900 .^{6}$

Mel Flikkema, of Kuyper College and Senior Advisor to the Kuyper Theological Society, contributes a foreword. In it he notes that this book anticipates a larger collection of Kuyper's writings on education.

The first address looks at the secret of study and is a translation of an address originally published in October 1889 by J. A. Wormser. At the time there were 124 students enrolled at the VU in three faculties.

Here Kuyper looks at 'the secret of genuine study'. He sees the university as a community of teachers and learners, where study is an 'inestimable privilege'. The need to hear God's call in the field of scholarship is emphasised, it is for God's honour that scholarship should be engaged in. It is for God's honour that we should investigate and wonder at his creation. Scientific research is a prerequisite to finding the "treasures that remain hidden in the world'. He highlights three things about science: it brings to light the hidden glory of God; it gives you joy in the act of digging up the gold that lies hidden in creation; and it grants you the honour of raising the level and well-being of human life (loc 208). He also exhorts the students to take care of their bodies: 'You have to exercise it, you have to keep it fresh' (loc 367).

The second address, Scholastica II from 1900, was also published by Wormser, and by then there were 229 students at the VU. Here Kuyper looks at the purpose of genuine study and uses the metaphors of 'seeking' and 'finding' to illustrate it. In hunting and fishing Kuyper asserts that the search is paramount, whereas in scholarship it is all about the finding.

In Scholastica I Kuyper quotes the saying 'great men have great faults' (loc 413). Kuyper was a great man and as de Bruijn's pictorial biography shows he also had his faults.

\section{ABRAHAM KUYPER: A PICTORIAL BIOGRAPHY}

In 1987, the VU mounted an exhibition to celebrate the 150th anniversary of Kuyper's birth. To celebrate that event Jan de Bruijn's Abraham Kuyper: Levenwerk in Beeld was published by Passage (de Bruijn 1987). In November 2008, a bronze statue of Kuyper was unveiled in Maassluis, to commemorate the fact that de Bruijn's Levenwerk was revised and updated (de Bruijn 2008). It was the latter that was translated into English by Dagmare Houniet (de Bruijn 2014). Houniet was also involved

$6 \quad$ These are designated 1889.14 and 1900.23 in Kuipers (2011) in the translation of Tjitze Kuipers' annotated bibliography (Kuipers 2011).

This book, weighing in at over $1.1 \mathrm{~kg}$, is lavish and beautifully produced. On each page there is at least one photograph with detailed supporting text. This is much more than an illustrated companion or supplement to Bratt's recent bibliography (Bratt 2013). De Bruijn fills in and highlights some of the details that Bratt was unable to include. Bratt is weak on Kuyper's family but de Bruijn has a strong emphasis on them. Several family portraits are included.

Particularly apparent is the way Kuyper treated his colleagues and the way in which his colleagues treated him following his prime ministerial role. Kuyper, it seems, was increasingly paranoid and wanted to hang on to power. He thought that some in his party were shutting him out.

There are many details that are in this book that I've not seen elsewhere. Kuyper and Lohman's antagonism towards each other is a key aspect that is highlighted in this book (see for example p. 268). Apparently Queen Wilhelmina wasn't fond of Kuyper (p. 268) and he was disliked by Lydia von Zarembra, the wife of Theo Heemskerkand (p. 270). She accused Kuyper of being a liar. There are photographs included of each of these people.

We are also informed of Kuyper's lack of church-going, as he used Sundays to write ... yet as Wood Jr. (2013) has shown, the church question was central to Kuyper's work.

The 'sawing incident' when Kuyper and friends broke into the church involved no saw - as the photograph of the church door confirms ( $\mathrm{p}$ 159). The term 'sawing the panel' was a reference to Laverti, a well-known burglar at the time.

We are treated to a quote by his daughter Henriette on his approach to writing under the familiar charcoal drawing by $\mathrm{J}$ an Veth that graces the cover of The centennial reader (Bratt 1998):

Dr. Kuyper writes, and for him writing is the immediate outpouring of his thoughts into visible signs. No outline, no points jotted in advance to show him the way. He puts down the paper in front of him, and from the thoughts crowded together, all inter-related, the ones that are called upon group themselves in such a way so as to spin out a thread that must lead to the foreseen goal. Immediately, as the stream of thought begins the pen ticks on the paper. At first slowly with round lettering: then, as the activity in the circle of thoughts increases, the more quickly and with smaller points and more little figures made up of dashes.

De Bruijn provides us with an excellent and fascinating pictorial introduction to Kuyper.

\section{CONCLUSIONS}

Is there no end to the production of kuyperania? Thankfully 
not, if these books are anything to go by. These four books illustrate different aspects of Kuyper's theological, political, educational career as well as his family life. They also are tasters of more to come - the Common grace volumes are still in the process of translation and a volume on education is planned of which Scholarship is a part. Kuyper's influence still continues as these books illustrate (and one literally!). The work of the Kuyper Translation project is now making accessible to the English-speaking world Kuyper's Dutch works, so we will see how fruitful Kuyper's legacy continues to be.

What these books show is that Kuyper's Calvinism was not restricted to soteriology; his approach was based on the sovereignty of God, cosmocentric rather than anthropocentric. His Christianity was integral to all that he did from theology to politics and education. 


\section{ACKNOWLEDGEMENTS}

\section{Competing interests}

The author declares that he has no financial or personal relationship(s) that may have inappropriately influenced him in writing this article.

\section{REFERENCES}

Bavinck, H., 1989, 'Common grace', translated by R.C. Van Leeuwen, Calvin Theological Journal 24(1), 38-65.

Bishop, S., 2014, 'Kuyperania in recent years', Koers - Bulletin for Christian Scholarship 79(1), Art. \#2138. http://www.koersjournal.org.za doi:10.4102/koers. v79i1.2138s.

Bratt, J.D., 2013, Abraham Kuyper: Modern Calvinist Christian Democrat, Eerdmans, Grand Rapids.

Bratt, J.D., 1998, Abraham Kuyper: A centennial reader, Eerdmans, Grand Rapids.

De Bruijn, J., 1987, Abraham Kuyper - leven en werk in beeld: Een beeldbiografie, Passage, Amsterdam.

De Bruijn, J., 2008, Abraham Kuyper: Een beeldbiografie, Bert Bakker, Amsterdam.

De Bruijn, J., 2014, Abraham Kuyper: A pictorial biography, Grand Rapids: Eerdmans.

Kuipers, T., 2011, Abraham Kuyper: An annotated bibliography 1857-2010, Brill, Leiden.

Kuyper, A., 2013a, Common grace: Volume 1: The historical section. Part 1: Noah-Adam, translated by Nelson D. Kloosterman and Ed M. van der Maas, edited by Jordan J. Ballor \& Stephen J. Grabill, Christian's Library Press, Grand Rapids.

Kuyper, A., 2013b, Guidance for Christian engagement in government, translated and edited by Harry van Dyke, Christian's Library Press, Grand Rapids.

Kuyper, A., 2014, Scholarship: Two convocation addresses on university life, translated by Harry van Dyke, Christian's Library Press, Grand Rapids.

Wood, J.H. Jr., 2013, Going Dutch in the modern age: Abraham Kuyper's struggle for a free church in the Netherlands, Oxford University Press, Oxford. 